\title{
THE USE OF CASSAVA PEEL (Manihot utilisima) FERMENTATION IN THE RATION ON THE FAT OF MALE LOCAL SHEEP
}

\author{
Ari Andani Nasution, Hasnudi, Nurzainah Ginting, Sayed Umar, Hamdan. \\ Animal Production Program Study, Faculty of Agriculture, University of North \\ Sumatera, Medan 20155, Indonesia \\ E-mail: ariandaninasution81094@gmail.com
}

Abstract. ARI ANDANI NASUTION, 2018: The Use Of Cassava Peel (Manihot Utilisima) Fermentation In The Ration On The Fat Of Male Local Sheep Under supervised by HASNUDI and NURZAINAH GINTING.

This study aims to determine how much influence the use of cassava peel (Manihot utilisima) fermentation in the rations on fat percentage of male local sheep. The research was conducted at the farm of Mr. Praditya located in Medan, in September-December 2017. The treatmen design used Completely Randomized Design (RAL) with 4 treatments and 5 replications. Using 20 local rams with an average of $10.18 \pm 1 \mathrm{~kg}$. The treatment provided is $P_{0}$ (Cassava peel Non Fermentation), $P_{1}$ (Cassava peel Fermentation 20\%), $P_{2}$ (Cassava peel Fermentation 40\%), and $P_{3}$ (Cassava peel Fermentation60\%). The results showed that the average the percentage of subcutaneous fat of sheep of highest $P_{3}=2.04$ dan low $P_{0}=1.10(\mathrm{~kg} / \mathrm{head})$. Average percentage of abdomen fat of highest $P_{0}=2.364$ and low $P_{3}=2.148(\mathrm{~kg} / \mathrm{head})$. Average percentage of heart of highest $P_{0} P_{2} P_{3}=0.204$ and low $P_{1}=0.198(\mathrm{~kg} / \mathrm{head})$. Average percentage of kidneys fat of highest $P_{2}=0.300$ and low $P_{0}=0.24$ $(\mathrm{kg} / \mathrm{head})$. Average percentage of pelvis fat of highest $P_{3}=0.284$ and low $P_{0}=0.262(\mathrm{~kg} / \mathrm{head})$. The conclusion of this research is the high use of fermented cassava peel in the ration can increase the percentage of subcutaneous fat and percentage of pelvis fat, butcauses the percentage of abdo men fat percentage of heart, and percentage of kidneys fat.

Keywords : Cassava peel, Fermentation, Fat, Local Lamb

\section{Introduction}

Feed is one factor that is very important and very influential on increasing livestock production. Provision of adequate feed ingredients with good quality is one of the elements that determine the success of livestock.

Seeing insufficient land availability as a forage provider, makes the availability of forages limited. The narrowness of forage land will have an impact on the growing needs of animal feed. To overcome this, need to look for an alternative feed that can replace the grass as animal feed. One of the agricultural waste that can be utilized as animal feed is the cassava peel. Cassava peel that are waste and its position is also always wasted after the tubers are taken for certain purposes, causing pollution to the environment if not used or processed properly. Utilization of cassava peel waste is certainly provide a positive value to a farm.

Sheep breeding is one source of meat and enough protein available and can be developed as a potential source of community nutrition. In general sheep cattle are traditionally kept by the community with 
minimal feed and a relatively small number of each family. To get a high percentage of carcass and good meat quality, among others is by improving feeding and determination of appropriate cutting weight.

Agricultural waste processing such as cassava peel as animal feed can be done by fermentation. Fermentation is one of the efforts to eliminate harmful substances for livestock and replaced with more useful substances such as increasing digestibility, protein content, lowering lignin and silage levels, adding flavor and aroma and increasing the content of minerals and vitamins in the diet.

Fat is a network that is dynamic, collected in many walls of the abdominal cavity and kidney. Fatty tissue is relatively stable from the influence of physical environmental nutrients compared to monogastric animals. According to states the amount of fat in the body is the most diverse and highly dependent on the amount of feed consumed [1].

\section{Materials and Research Methods}

This research was conducted at local lamb farm owned by Mr. Praditya located at Street Flower Rinte Kec. Medan Tuntungan, Medan. This study lasted for approximately three months, starting from September to December 2017.

Materials used include: Local Sheep Hair Sheep Male as much as 20 tail with weight average of $10.18 \pm 1$ $\mathrm{kg}$ used as a research object. Feed ingredients used are forage, Starbio as fermentor of cassava peel flour (Manihot utilisima) and concentrate such as tofu, soybean meal, molasses, ultra mineral, salt, urea, medicines such as worm medicine (kalbazen), anti bloat for bloating and vitamins. Drinking water to meet the water requirement given adlibitum.

Equipment used include: individual cages 20 units and equipments, feed and drink, live weight scale and carcass weighing $50 \mathrm{~kg}$ with sensitivity $10 \mathrm{~g}, 2 \mathrm{~kg}$ weight scale with sensitivity $5 \mathrm{~g}$ for weighing feed, drum tool for fermentation of leather flour cassava bulbs, cage cleaners, cage lighting equipment, stationery, data books and calculators.

The experimental design used research is Completely Randomized Design (CRD) with 4 treatments and 5 repetitions. The treatment in this research is $\mathrm{P} 0=$ Flour Cassava Peel Fermentation $0 \%+$ Flour Cassava Peel Non - Fermentation $60 \%$ + Field Grass 20\% + Concentrate 20\%; P1 = Flour Cassava Peel Fermentation 20\% + Flour Cassava Peel Non - Fermentation 40\% + Field Grass 20\% + Concentrate 20\%; P2 : Flour Cassava Peel Fermentation 40\% + Flour Cassava Peel Non - Fermentation 20\% + Field Grass 20\% + Concentrate 20\%; P3 : Flour Cassava Peel Fermentatation 60\% + Flour Cassava Peel Non Fermentation $0 \%$ + Field Grass $20 \%$ + Concentrate $20 \%$.

Parameter of Research is Fat percentage (\%), Percentage of Subcutaneous Fats $(\%)=$ that is obtained from the comparison of subcutaneous fat weight with carcass weight $100 \%$. Abdominal fat percentage $(\%)=$ which is obtained from the ratio of abdominal fat weight to carcass weight $100 \%$. Percentage of heart fat $=$ namely fat obtained from fat covering the heart divided by carcass weight multiplied by $100 \%$. Percentase of renal fat $(\%)=$ that is obtained from the ratio of fat weight of the kidney with carcass weight 100 times. Percentage of pelvic fat $(\%)=$ That is obtained from the ratio of fat weight of the pelvis with carcass weight 100 times.

\section{Results and Discussion}

\subsection{Percentage of Subcutaneous Fats}

The percentage of subcutaneous fat was obtained from the comparison between the weight of subcutaneous fat and the carcass weight of $100 \%$. The data was processed by the method of SAS and then continued with Duncan test so that it is known that the treatment the highest percentage on P3 treatment was 2.04 and the lowest was in P0 treatment of 1.10. Where the average of percentage of subcutaneous fat can be seen in Table 1 .

Table 1. Average percentage of subcutaneous fat of local sheep sheep (Hair Sheep) males influence the use of fermented cassava peel on rations (\%). 


\begin{tabular}{|c|c|c|c|c|c|c|c|}
\hline \multirow{2}{*}{ Treatment } & \multicolumn{5}{|c|}{ Repetition } & \multirow{2}{*}{ Completely } & \multirow{2}{*}{ Average } \\
\hline & U1 & $\mathrm{U} 2$ & $\mathrm{U} 3$ & $\mathrm{U} 4$ & U5 & & \\
\hline $\mathrm{P} 0$ & 1.02 & 1.10 & 1.20 & 1.02 & 1.18 & 5.52 & $1.10 \pm 0.08^{\mathrm{C}}$ \\
\hline $\mathrm{P} 1$ & 1.13 & 1.82 & 1.13 & 1.10 & 1.15 & 6.33 & $1.27 \pm 0.31^{\mathrm{BC}}$ \\
\hline $\mathrm{P} 2$ & 1.76 & 1.76 & 2.03 & 1.76 & 1.12 & 8.43 & $1.69 \pm 0.33^{\mathrm{AB}}$ \\
\hline $\mathrm{P} 3$ & 2.48 & 2.38 & 1.11 & 2.47 & 1.74 & 10.18 & $2.04 \pm 0.60^{\mathrm{A}}$ \\
\hline Completely & 6.39 & 7.06 & 5.47 & 6.35 & 5.19 & 30.46 & \\
\hline Avarage & 1.60 & 1.77 & 1.37 & 1.59 & 1.30 & & 1.52 \\
\hline
\end{tabular}

Description: Different superscripts in the same column show a very significant different effect $(\mathrm{P}<0.01)$.

According to statement [2] which states that the higher the carcass weight the percentage of meat and fat increases as well. But in contrast to who stated that in younger sheep the percentage of bones higher, but otherwise the percentage of meat / carcass and fat is lower. This is due to the sheep still growing on the weight of builder tissues, such as tendon, bone, brain bone, heart and all body tissues.

\subsection{Percentage of Abdominal Fat}

Abdominal fat percentage was obtained from comparison between abdominal fat weight and carcass weight $100 \%$. The data was processed by the method of SAS and then continued with Duncan test so that it is known that the treatment the highest abdominal fat percentage found in treatment P0 of 2.364 and the lowest was in treatment P3 of 2.148. Average sheep Abdominal fat percentage can be seen in Table 2.

Table 2. Mean abdominal fat percentage of local sheep sheep (Hair Sheep) males influence skin use of fermented cassava peel on ration $(\%)$

\begin{tabular}{cccccccc}
\hline Treatment & \multicolumn{3}{c}{ Repetition } & \multicolumn{3}{c}{ Completely } & Average \\
\hline & $\mathrm{U} 1$ & $\mathrm{U} 2$ & $\mathrm{U} 3$ & $\mathrm{U} 4$ & $\mathrm{U} 5$ & & \\
\hline P0 & 2,31 & 1,74 & 2,66 & 2,48 & 2,63 & 11,820 & $2.364 \pm 0.37^{\mathrm{a}}$ \\
P1 & 2,53 & 2,63 & 1,78 & 1,74 & 2,65 & 11,330 & $2.266 \pm 0.46^{\mathrm{a}}$ \\
P2 & 2,54 & 2,08 & 2,05 & 2,06 & 2,39 & 11,120 & $2.224 \pm 0.22^{\mathrm{a}}$ \\
P3 & 2,16 & 2,16 & 1,76 & 2,16 & 2,5 & 10,740 & $2.148 \pm 0.26^{\mathrm{a}}$ \\
\hline Completely & 9,540 & 8,610 & 8,250 & 8,440 & 10,170 & 45,010 & \\
\hline Average & 2,385 & 2,153 & 2,063 & 2,110 & 2,543 & & 2,251 \\
\hline
\end{tabular}

Description: Different superscripts in the same column show a very significant different effect $(\mathrm{P}<0.01)$.

According to [3] which states that the accumulation of fat in the abdominal is not desirable, because it will reduce the difference between the weight of life and weight. One way to reduce fatty acids is to vary the nutrient rations, especially energy and protein. Increasing the energy content of the ration will increase the fat content and increase the protein ration then the amount of abdominal fat will decrease.

\subsection{Percentage of Heart Fat}

The Percentage of Heart Fat was obtained from the comparison between the weight of heart fat and carcass weight $100 \%$. The data was processed by the method of SAS so that it is known that the treatment the highest The highest percentage of heart fat was found in P0 treatment, P2 and P3 were $0.204 \%$ and the lowest percentage of heart fat was found in P1 treatment that was $0.198 \%$. Average Percentage of Heart Fat can be seen in Table 3.

Table 3. Meaning of local sheep Percentage of Heart Fat (Hair Sheep) males influence the use of fermented cassava peel $(\mathrm{kg})$. 


\begin{tabular}{|c|c|c|c|c|c|c|c|}
\hline \multirow{2}{*}{ Treatment } & \multicolumn{5}{|c|}{ Repetition } & \multirow{2}{*}{ Completely } & \multirow{2}{*}{ Average } \\
\hline & $\mathrm{U} 1$ & $\mathrm{U} 2$ & U3 & $\mathrm{U} 4$ & U5 & & \\
\hline P0 & 0.210 & 0.180 & 0.220 & 0.200 & 0.210 & 1.020 & $0.204 \pm 0.01^{\mathrm{a}}$ \\
\hline $\mathrm{P} 1$ & 0.200 & 0.220 & 0.180 & 0.180 & 0.210 & 0.990 & $0.198 \pm 0.02^{\mathrm{a}}$ \\
\hline $\mathrm{P} 2$ & 0.200 & 0.200 & 0.200 & 0.200 & 0.220 & 1.020 & $0.204 \pm 0.01^{\mathrm{a}}$ \\
\hline $\mathrm{P} 3$ & 0.210 & 0.210 & 0.200 & 0.200 & 0.200 & 1.020 & $0.204 \pm 0.01^{\mathrm{a}}$ \\
\hline Completely & 0.820 & 0.810 & 0.800 & 0.780 & 0.840 & 4.050 & \\
\hline Average & 0.205 & 0.203 & 0.200 & 0.195 & 0.210 & & 0.203 \\
\hline
\end{tabular}

Description: Different superscripts in the same column show a significantly different effect $(\mathrm{P}<0.05)$.

In accordance with the statement of [4] which states that the weight of fat that is found around the bottom of the skin, kidneys, pelvis and heart have an effect on the quality of carcass, because with increased fat will result in reduced commercial carcass.

In accordance with the statements of [5] which states that the variety of body fat caused by differences in body growth depending on the nation, age, gender and background feed.

\subsection{Percentage of Kidney Fat}

Percentage of Kidney Fat obtained from from the ratio of renal fat weight to carcass weight $100 \%$. The data was processed by the method of SAS and then continued with Duncan test so that it is known that the treatment the highest percentage of renal fat was found in the P2 treatment of 0,300 and the lowest percentage of renal fat was found in the P0 treatment of 0.242.Average percentage of Kidney Fat of sheep carcass can be seen in Table 4.

Table 4. Average percentage of Kidney Fat local sheep (Hair Sheep) males influence use of fermented cassava peel $(\%)$.

\begin{tabular}{|c|c|c|c|c|c|c|c|}
\hline \multirow{2}{*}{ Treatment } & \multicolumn{5}{|c|}{ Repetition } & \multirow{2}{*}{ Completely } & \multirow{2}{*}{ Average } \\
\hline & U1 & $\mathrm{U} 2$ & U3 & U4 & U5 & & \\
\hline $\mathrm{P} 0$ & 0.230 & 0.250 & 0.250 & 0.240 & 0.240 & 1.210 & $0.242 \pm 0.01^{\mathrm{a}}$ \\
\hline $\mathrm{P} 1$ & 0.230 & 0.370 & 0.250 & 0.250 & 0.270 & 1.370 & $0.274 \pm 0.05^{\mathrm{a}}$ \\
\hline $\mathrm{P} 2$ & 0.350 & 0.290 & 0.270 & 0.300 & 0.290 & 1.500 & $0.300 \pm 0.03^{\mathrm{a}}$ \\
\hline $\mathrm{P} 3$ & 0.280 & 0.280 & 0.260 & 0.280 & 0.350 & 1.450 & $0.290 \pm 0.03^{\mathrm{a}}$ \\
\hline Completely & 1.090 & 1.190 & 1.030 & 1.070 & 1.150 & 5.530 & \\
\hline Average & 0.273 & 0.298 & 0.258 & 0.268 & 0.288 & & 0.277 \\
\hline
\end{tabular}

Description: The same superscript in the same column shows an unreal effect $(\mathrm{P}>0.05)$.

According to [6] fat is a dynamic network, collected in the walls of the stomach and kidney cavities. Fat weight is influenced by the amount of feed consumed, this is in accordance with the statement [5] which states that the fatty tissue in the body is the most bergam and highly dependent on the amount of food consumed.

\subsection{Percentage of Lamb's Pelvic Fat}

Percentage of Lamb's Pelvic Fat was obtained from the comparison between the weight of the pelvic fat and the carcass weight by $100 \%$. The data was processed by the method of SAS and then continued with Duncan test so that it is known that the treatment the highest percentage of fat was found in P3 treatment that was 0.284 and the lowest percentage of pelvic fat was found in treatment P0 which was 0.262. Average percentage of Lamb's Pelvic Fat of sheep can be seen in Table 4. 
Table 4. Average percentage of Lamb's Pelvic Fat local sheep (Hair Sheep) males influence use of fermented cassava peel $(\%)$.

\begin{tabular}{cccccccc}
\hline Treatment & \multicolumn{9}{c}{ Repetition } & Completely & Average \\
\hline & U1 & U2 & U3 & U4 & U5 & & \\
\hline & & & & & & & \\
P0 & 0.250 & 0.260 & 0.250 & 0.290 & 0.260 & 1.310 & $0.262 \pm 0.06^{\mathrm{b}}$ \\
P1 & 0.250 & 0.280 & 0.270 & 0.260 & 0.250 & 1.310 & $0.262 \pm 0.01^{\mathrm{b}}$ \\
P2 & 0.270 & 0.280 & 0.280 & 0.290 & 0.260 & 1.380 & $0.276 \pm 0.01^{\mathrm{ab}}$ \\
P3 & 0.290 & 0.290 & 0.280 & 0.290 & 0.270 & 1.420 & $0.284 \pm 0.01^{\mathrm{a}}$ \\
\hline Completely & 1.060 & 1.110 & 1.080 & 1.130 & 1.040 & 5.420 & \\
\hline Average & 0.265 & 0.278 & 0.270 & 0.283 & 0.260 & & 0.271 \\
\hline
\end{tabular}

Description: The same superscript in the same column shows an unreal effect $(\mathrm{P}>0.05)$.

The percentage of fat is very diverse and tends to increase with the increase of cattle age. This is in accordance with the statement [7] which states that the increasing age, the body weight will increase as well. Fat will be in the heap during growth and development, in accordance with the growth pattern of karka components that begins with rapid growth, then after reaching puberty the growth rate of fat increases.

\section{Conclusions}

The use of cassava cassava flour (Manihot utilisima) fermented with starbio to 60\% level in ration can increase the percentage of fat Subcutaneous and Pelvic Fats but decrease abdominal fat percentage, percentage of heart fat and percentage of kidney fat.

\section{References}

[1] Crouse., J. D, J. R. Busborn, R. A. Field and C. L. Feller., 1981. Effect of Breed, Diet, Sex, Location and Weight Weight on Lambs Growth, Carcass Composition and Meat Flavor, Mc Garaw Hil . Book Company, New York.

[2] Sugeng, B.Y. 1991. Sheep Farming. Self-helpers. Jakarta.

[3] Hasibuan, J, M., 1996. Effect of Cattle Rumen Content as Bran Subtitles in the Ration Against Body Weight, Carcass and Fat Abdominal Chicken Broiler, Department of Animal Husbandry, Faculty of Agriculture, USU, Medan.

[4] Minish, G. L. and D. G Fox. 1976. Beef Production and Management. Preston Pub. Co. Inc. Restron Virginia.

[5] Berg and Butterfield, 1976. New Concept of Cattle Growth. Sydney University Press.

[6] Atmowijoyo, M., T. Warsiti, A. Purnomoadi and W. S. Dilaga. 1980. Development of Meat Quality at Local Sheep that are Maintained Intensively. Proceedings of the National Seminar on Animal and Veterinary Technology.

[7] Soeparno .2011. Meat Science and Technology. The fourth print. Gadjah Mada University Press, Yogyakarta. 